\title{
Unified power quality conditioner supplied by fuel cell system via SEPIC converter
}

Benabid Slimane, Abdelkhalek Othmane, Ben Abdelkader Abdallah

Department of Electrical of Engineering, Tahri Mohammed Bechar University, Algeria

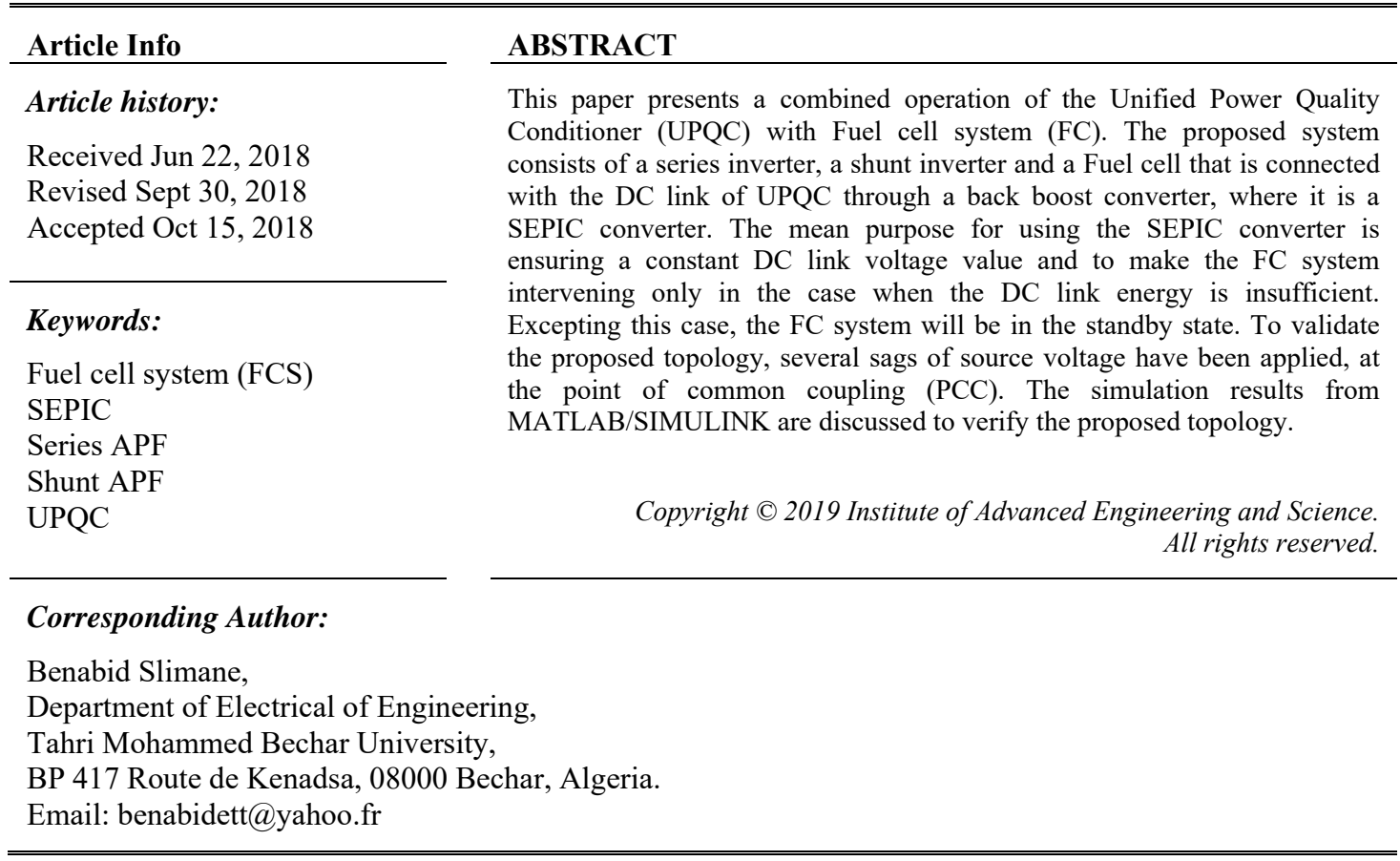

\section{INTRODUCTION}

The existing power distribution networks face huge poor power quality problems and reactive power requirement due to increased use of nonlinear and inductive loads [1]-[4]. Nevertheless, the same advancement in power electronic devices offers solutions for reactive power compensation and power quality improvement in the form of active power filters (APFs). The two types of APFs are shunt and series APF. The shunt APFs are used to mitigate current harmonics and reactive power compensation. The series APFs are used to compensate voltage related problems, such as voltage harmonics, sags, swells, unbalances, flicker, etc.

The UPQC is the most widely used active power filter in distribution networks to solve both current and voltage related disturbances simultaneously [5]. It is the integration of shunt and series APFs through a common DC link capacitor. UPQC has been widely studied to eliminate or mitigate the disturbances propagated from the source side and the other loads interconnected [6]. In the normal operation of UPQC, the shunt APF control circuit calculates the harmonic currents compensation and generates the inverter pulses to power circuits (shunt APF). The series APF compensates the harmonics and the all other voltage disturbances. The arrangement of series and shunt filters are interchangeable.

In general, when a UPQC is used in a power distribution system, the series filter is installed ahead of the shunt filter. There are many control strategies reported in the literature to control the UPQC for power quality improvements, the most common of which are the instantaneous active and reactive power theory (PQ method) proposed by Fujita and Akagi, symmetric component transformation, synchronous reference frame (SRF) theory, and unit template technique (UTT) etc.

The series APF systems need certainty to provide active power into the power system to maintain the load voltage level during voltage sag. At the same time, the power flow in the series APF system has 
drastically increased during the source voltage sag. Thus, additional energy sources need to be added into the series APF system DC-link. In the latest decade due to the extreme rise in the price of fossil fuels and environmental pollution associated with the use of nuclear and fossil fuels [7].

A fuel cell is a device that directly converts the chemical energy of fuel to electric energy. Recent advances in the fuel cell technology significantly improved the technical and economical characteristics of this technology. Environmental friendliness, practically noise free operation, and very high efficiency combined with the forecasted shift to gaseous fuels make fuel cells a very sound competitor on the future electricity markets [8], [9]. However, FC can cause the negative effects on the existing power systems. That is, some potential problems might be occurred such as voltage variation, protection, harmonics, and personnel safety. The FC is interfaced in the AC and DC distributed system by using power electronic circuits. The DC voltage must be limited within an acceptable range during steady state and dynamic conditions by using suitable control strategies.

This paper proposes a combined operation system of UPQC and fuel cell, which is connected to the dc link. The advantage of the proposed system over the UPQC is to compensate the voltage interruption, as well as the voltage sag, harmonics. The operation of the proposed system was verified through simulations with MATLAB/Simulink. Figure 1 shows general configuration of the UPQC - FC system.

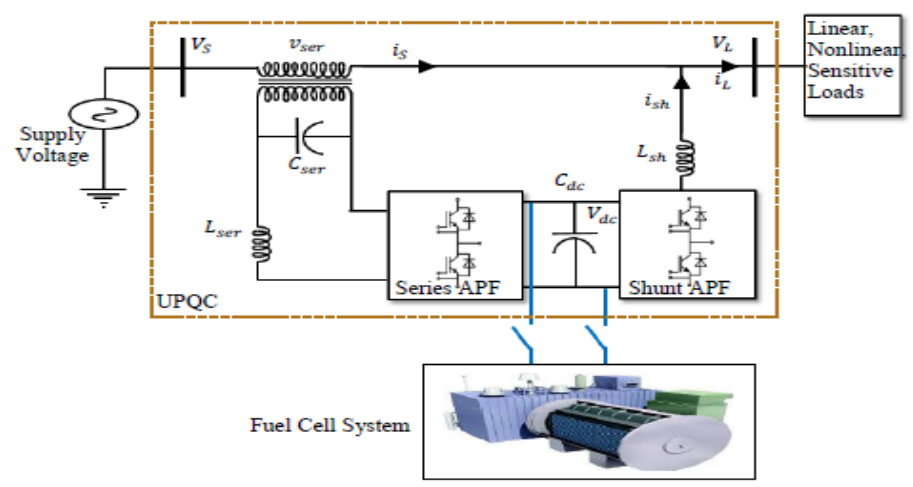

Figure 1. General configuration of the UPQC - FC system

\section{THE COMPREHENSIVE THEORETICAL BASIS}

\subsection{Modeling and characteristics of FC stack}

A fuel cell is an electrochemical device that converts chemical energy into electrical energy, by means of a chemical reaction in an electrolyte, generating water [10], [11] and heat as waste [12]. There are many types of fuel cells, differentiated mainly by the electrolyte used. A schematic diagram of a generic fuel cell is shown in Figure 2.

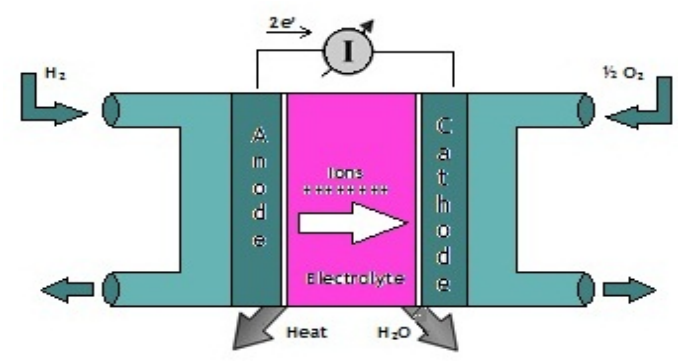

Figure 2. Schematic diagram of fuel cell [10]

In the proposed system, a PEMFC in the Ohmic Polarization Region [13] is used because they show adequate operation characteristics for the voltage, current and power levels under consideration. PEMFC is emerging as one of the most promising technologies when dealing with the replacement of fossil fuels for

Unified power quality conditioner supplied by fuel cell system via SEPIC converter (Benabid Slimane) 
electric power generation. The fuel cell consists on the stack of 900 elements with a nominal power of $50 \mathrm{~kW}$ at a nominal voltage of $625 \mathrm{~V}$ with a maximum efficiency of $55 \%$. The mathematical model is developed in the toolbox "SimPowerSystems" of Matlab/ Simulink [14]. The PEMFC is preferred operated in the Ohmic region because of the better efficiency [15]. One disadvantage of the fuel cells is that the voltage is not constant but varies with the current taken from the cell.

Then, the use of power electronics converters is essential to interface the PEMFC with the electric systems regardless of the cell operating point. The MCSI allows to adjust the current taken from the cell to get as close as possible to the zone of maximum efficiency [16]. The FCs are connected in series to give sufficient DC voltage, it results in a FC stack. The FC stack can be modeled as a controlled voltage source E in series with a constant resistance Rfc as shown in Figure 3.

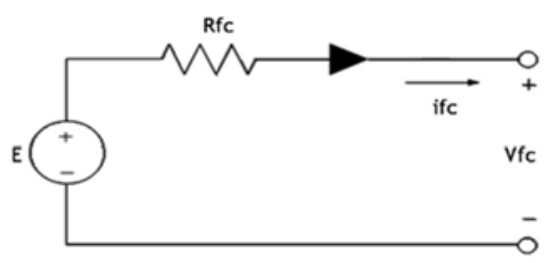

Figure 3. Fuel cell stack model

The controlled voltage source can be represented as :

$$
\mathrm{E}=\mathrm{E}_{\mathrm{OC}}-\mathrm{N} \cdot \mathrm{A} \cdot \ln \left(\frac{\mathrm{i}_{\mathrm{fc}}}{\mathrm{i}_{\mathrm{o}}}\right.
$$

and FC stack output voltage as

$$
\mathrm{V}_{\mathrm{fc}}=\mathrm{E}-\mathrm{R}_{\mathrm{fc}} \cdot \mathrm{i}_{\mathrm{fc}}
$$

where $E_{0 c}$ is the open circuit voltage, $\mathrm{N}$ is the number of cells in the stack, $\mathrm{A}$ is the Tafel slope, $\mathrm{i}_{0}$ is the exchange current resulting from the continual backward and forward flow of electrons from and to the electrolyte at no load. $\mathrm{R}_{\mathrm{fc}}$ is the internal resistance of the FC stack. $\mathrm{i}_{\mathrm{fc}}$ is the FC stack current and $\mathrm{V}_{\mathrm{fc}}$ is the FC stack voltage. The Tafel Slope, exchange current and the open circuit voltage are affected by variations in temperature and partial pressures of hydrogen and oxygen.

They can be represented as:

$$
\begin{aligned}
& \mathrm{E}_{\mathrm{OC}}=\mathrm{K} \cdot \mathrm{E}_{\mathrm{n}} \\
& \mathrm{i}_{0}=\frac{\mathrm{z} \cdot \mathrm{F} \cdot \mathrm{k}\left(\mathrm{P}_{\mathrm{H} 2}+\mathrm{P}_{\mathrm{O} 2}\right)}{\mathrm{R} \cdot \mathrm{h}} \exp \left(\frac{-\Delta \mathrm{G}}{\mathrm{RT}}\right) \\
& \mathrm{A}=\frac{\mathrm{R} \cdot \mathrm{T}}{\mathrm{z} \cdot \mathrm{\cdot} \cdot \mathrm{F}}
\end{aligned}
$$

where $E_{n}$ is the Nernst voltage, the thermodynamics voltage of the cells and depends on the temperature and partial pressures of reactants inside the stack and is given as:

$$
\mathrm{E}_{\mathrm{n}}=0,229+(\mathrm{T}-298)\left(\frac{-44,43}{\mathrm{z} \cdot \mathrm{F}}\right)+\frac{\mathrm{R} \cdot \mathrm{T}}{\mathrm{z} \cdot \mathrm{F}} \ln \left(\mathrm{P}_{\mathrm{H} 2} \cdot \mathrm{P}_{\mathrm{O} 2}\right)^{\frac{1}{2}}
$$

where $\alpha$ is the charge transfer coefficient, which depends on the type of used electrodes and catalysts. T is the operating temperature of the cell, $\mathrm{P}_{\mathrm{H} 2}$ is the partial pressure of hydrogen inside the stack, $\mathrm{P}_{\mathrm{O} 2}$ is the partial pressure of oxygen inside the stack, $F$ is the Boltzmann's constant $(1,38 \times 10-23 \mathrm{j} / \mathrm{K})$, $\mathrm{h}$ is the Plank's constant $(6,626 \times 10-34 \mathrm{Js}) . \Delta \mathrm{G}$ is the size of the activation barrier, which depends on the type of electrode and catalyst used, $\mathrm{z}$ is the number of moving electrons and $\mathrm{K}$ is the voltage constant at nominal operating condition.

Int J Pow Elec \& Dri Syst, Vol. 10, No. 1, March 2019: $178-194$ 
The modeling of PEMFC is based on the $(1) \sim(6)$. The experimental measured voltage-current $(\mathrm{V}-\mathrm{I})$ characteristic of NedStack $100 \mathrm{~kW}$ PEMFC is used to drive the Matlab/Simulink model of the FC stack. Figure 4 shows the V-I and P-I characteristic of FC Stack.
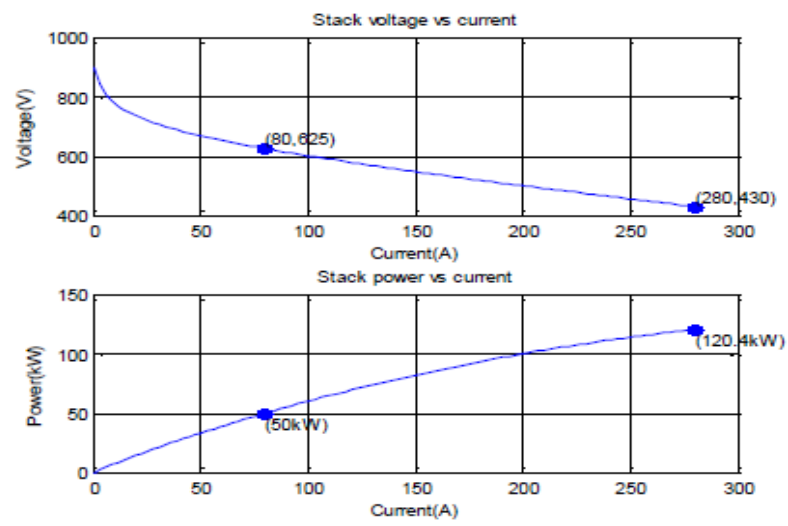

Figure 4. The voltage-current and power-current characteristic of fuel cell stack

Four points are taken on the V-I curve for determining the parameters Eoc,io,N, A and Rfc. These points correspond to current and voltage at maximum operating point (Imax, Vmin and to current and voltage at nominal operating point (Inom, Vnom), and voltage at 0A current (Eoc) and voltage at 1A current (V1). the FC stack parameters extracted from the Nedstack. The following formulations are derived from (1)-(2)

$$
\begin{aligned}
& V_{1}=E_{O C}-N \cdot A \cdot \ln \left(i_{0}\right)-R_{f c} \\
& V_{\text {nom }}=E_{O C}-N \cdot A \cdot \ln \left(\frac{I_{\text {nom }}}{I_{0}}\right)-R_{f c} \cdot I_{\text {nom }} \\
& V_{\text {min }}=E_{O C}-N \cdot A \cdot \ln \left(\frac{I_{\max }}{I_{0}}\right)-R_{f c} \cdot I_{\text {nom }}
\end{aligned}
$$

Solving equations $(7) \sim(9)$, we get

$$
\begin{aligned}
& N \cdot A=\frac{\left(V_{1}-V_{\text {nom }}\right)\left(I_{\max }-1\right)-\left(V_{1}-V_{\min }\right)\left(I_{\text {nom }}-1\right)}{\ln \left(I_{\text {nom }}\right)\left(I_{\max }-1\right)-\ln \left(I_{\max }\right)\left(I_{\text {nom }}-1\right)} \\
& R_{f c}=\frac{V_{1}-V_{\text {nom }}-N A \ln \left(I_{\text {nom }}\right)}{I_{\text {nom }}-1} \\
& i_{0}=\exp \left(\frac{V_{1}-E_{O C}+R_{f c}}{N A}\right)
\end{aligned}
$$

Therefore, from the four points on the polarization curve, the values of Io, Rfc and N.A are derived. The material parameters $\mathrm{K}, \Delta \mathrm{G}$ and $\alpha$ are calculated founded on the polarization curve at nominal operating conditions sideways with some additional parameters, such as the composition of fuel and air, supply pressures and temperatures, the low heating value efficiency of the stack etc. [17]-[19].

\subsection{Modeling and characteristics of UPQC}

The UPQC device contains a series and shunt active power filter (APF) with a mutual DC link capacitor. The compensation capability of UPQC device is determined by the degree of DC link voltage stability.

\subsubsection{Shunt active power filter}

The parallel active power filter (PAPF) control strategy is based on the SRF detection method [20]. Figure 5 shows the PAPF strategy control. 


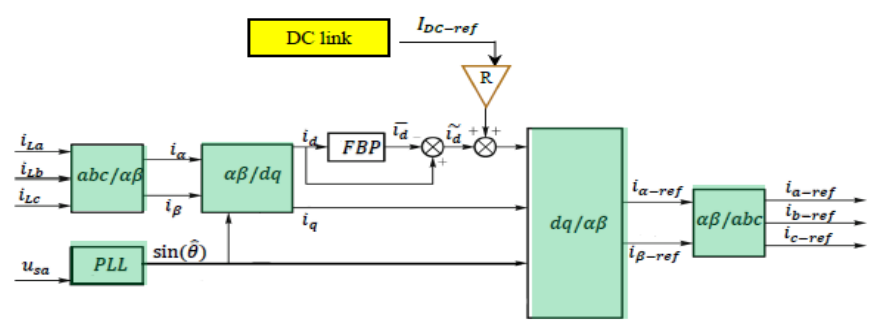

Figure 5. The PAPF strategy control

This method is adopted to compensate harmonic currents and reactive currents as well as to regulate the common dc-link capacitor voltage. The principle of this technique is described below. The three-phase load currents iLa, iLb and iLc are transformed from three phases (abc) reference frame to two phase's $(\alpha-\beta)$ stationary reference frame currents $i \alpha$ and i $\beta$ using:

$$
\left[\begin{array}{l}
\mathrm{i}_{\alpha} \\
\mathrm{i}_{\beta}
\end{array}\right]=\sqrt{\frac{2}{3}}\left[\begin{array}{ccc}
1 & -\frac{1}{2} & \frac{1}{2} \\
0 & \frac{\sqrt{3}}{2} & -\frac{\sqrt{3}}{2}
\end{array}\right]\left[\begin{array}{c}
\mathrm{i}_{\mathrm{La}} \\
\mathrm{i}_{\mathrm{Lb}} \\
\mathrm{i}_{\mathrm{Lc}}
\end{array}\right]
$$

Using a PLL, $\cos (\theta$ est $)$ and $\sin (\theta$ est $)$ can be generated from the phase voltage source usa, usb and usc. The $i \alpha$ and i $\beta$ currents expression in (d-q) reference frame are given by:

$$
\left[\begin{array}{l}
\mathrm{i}_{\mathrm{d}} \\
\mathrm{i}_{\mathrm{q}}
\end{array}\right]=\left[\begin{array}{cc}
\sin \left(\theta_{\text {est }}\right) & -\cos \left(\theta_{\text {est }}\right) \\
\cos \left(\theta_{\text {est }}\right) & \sin \left(\theta_{\text {est }}\right)
\end{array}\right]\left[\begin{array}{c}
\mathrm{i}_{\alpha} \\
\mathrm{i}_{\beta}
\end{array}\right]
$$

The current id is transformed to DC and harmonic components using a low pass filter

$$
\left[\begin{array}{c}
\mathrm{i}_{\mathrm{d}} \\
\mathrm{i}_{\mathrm{q}}
\end{array}\right]=\left[\begin{array}{c}
\overline{\mathrm{i}}_{\mathrm{d}}+\tilde{\mathrm{i}}_{\mathrm{d}} \\
\mathrm{i}_{\mathrm{q}}
\end{array}\right]
$$

The expression of the reference currenti ${ }_{-}$ref and i $\beta$ _refare given by

$$
\begin{aligned}
& {\left[\begin{array}{l}
\mathrm{i}_{\alpha \_ \text {ref }} \\
\mathrm{i}_{\beta \_ \text {ref }}
\end{array}\right]=\left[\begin{array}{cc}
\sin \left(\theta_{\text {est }}\right) & -\cos \left(\theta_{\text {est }}\right) \\
\cos \left(\theta_{\text {est }}\right) & \sin \left(\theta_{\text {est }}\right)
\end{array}\right]^{-1}\left[\begin{array}{c}
\mathrm{i}_{\mathrm{d}} \\
\mathrm{i}_{\mathrm{q}}
\end{array}\right]} \\
& {\left[\begin{array}{c}
\mathrm{i}_{\alpha_{\alpha} \text { ref }} \\
\mathrm{i}_{\beta-\text { ref }}
\end{array}\right]=\left[\begin{array}{cc}
\sin \left(\theta_{\text {est }}\right) & \cos \left(\theta_{\text {est }}\right) \\
-\cos \left(\theta_{\text {est }}\right) & \sin \left(\theta_{\text {est }}\right)
\end{array}\right]\left[\begin{array}{c}
\overline{\mathrm{i}}_{\mathrm{d}}+\tilde{\mathrm{i}}_{\mathrm{d}} \\
\mathrm{i}_{\mathrm{q}}
\end{array}\right]}
\end{aligned}
$$

The correspondent reference currents in the (abc) frame are given by:

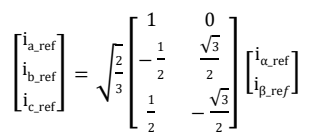

Finally, the compensation currents ica, icb and icc are given by:

$$
\begin{aligned}
& \mathrm{i}_{\text {ca }}=\mathrm{i}_{\mathrm{a}_{\_} \text {ref }}-\mathrm{i}_{\mathrm{La}} \\
& \mathrm{i}_{\mathrm{cb}}=\mathrm{i}_{\mathrm{b} \_ \text {ref }}-\mathrm{i}_{\mathrm{Lb}} \\
& \mathrm{i}_{\mathrm{cc}}=\mathrm{i}_{\mathrm{c} \_ \text {ref }}-\mathrm{i}_{\mathrm{Lc}}
\end{aligned}
$$

For regulating the DC link voltage Udc, and compensating the inverter losses, a proportional integral (PI) voltage controller is used. The control loop be made up of the comparison between the measured voltage $(\mathrm{Udc} 1+\mathrm{Udc} 2)$ and the reference voltage Udc_ref. The loop generates corresponding current Idc_ref as given by:

$$
\mathrm{I}_{\mathrm{dC} \_ \text {ref }}=\mathrm{K}_{\mathrm{P}} \cdot \Delta \mathrm{U}_{\mathrm{DC}}+\mathrm{K}_{\mathrm{I}} \int \Delta \mathrm{U}_{\mathrm{DC}} \cdot \mathrm{dt}
$$




\subsubsection{Shunt Active Power Filter}

The control strategy used to extract the reference voltages of series active power filter (SAPF) is based on the PQ method [21]. Series active power filter strategy control, as shown in Figure 6.

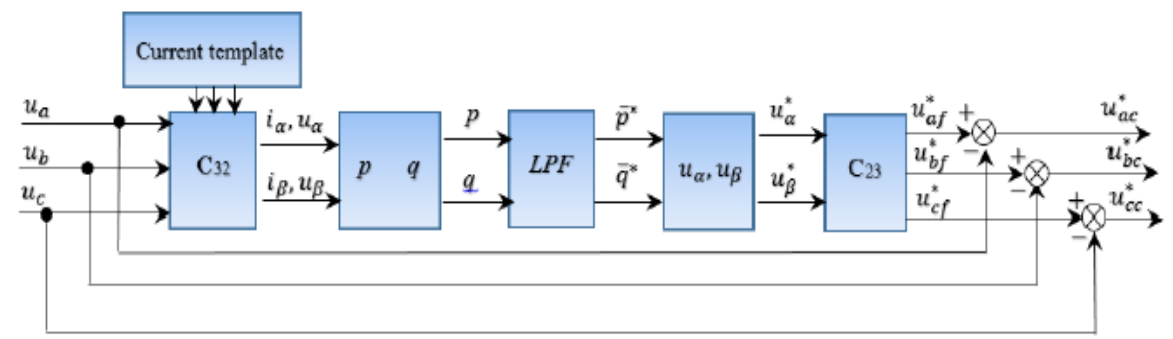

Figure 6. Series active power filter strategy control

The grid three-phase voltage source is assumed to be symmetric and not distorted

$$
\left[\begin{array}{l}
u_{a} \\
u_{b} \\
u_{c}
\end{array}\right]=\left[\begin{array}{c}
\sum_{n=1}^{\infty} \sqrt{2} U_{n} \sin \left(n \omega t+\theta_{n}\right) \\
\sum_{n=1}^{\infty} \sqrt{2} U_{n} \sin \left(\left(n \omega t-\frac{2 \pi}{3}\right)+\theta_{n}\right) \\
\sum_{n=1}^{\infty} \sqrt{2} U_{n} \sin \left(\left(n \omega t+\frac{2 \pi}{3}\right)+\theta_{n}\right)
\end{array}\right]
$$

Where $U n$ and $\theta n$ are respectively the root mean square (rms) voltage and initial phase angle, $n$ is the harmonic order. When $n=1$, it means three-phase fundamental voltage source:

$$
\left[\begin{array}{l}
u_{s a} \\
u_{s b} \\
u_{s c}
\end{array}\right]=\left[\begin{array}{c}
\sqrt{2} U_{1} \sin \left(\omega t+\theta_{1}\right) \\
\sqrt{2} U_{1} \sin \left(\left(\omega t-\frac{2 \pi}{3}\right)+\theta_{1}\right) \\
\sqrt{2} U_{1} \sin \left(\left(\omega t+\frac{2 \pi}{3}\right)+\theta_{1}\right)
\end{array}\right]
$$

From (22) is transformed into $(\alpha-\beta)$ reference frame

$$
\begin{aligned}
& {\left[\begin{array}{l}
u_{\alpha} \\
u_{\beta}
\end{array}\right]=C_{32}\left[\begin{array}{l}
u_{s a} \\
u_{s b} \\
u_{s c}
\end{array}\right]=\sqrt{3}\left[\begin{array}{c}
\sum_{n=1}^{\infty} U_{n} \sin \left(n \omega t+\theta_{n}\right) \\
\sum_{n=1}^{\infty} \pm U_{n} \sin \left(n \omega t+\theta_{n}\right)
\end{array}\right]} \\
& C_{32}=\sqrt{\frac{2}{3}}\left[\begin{array}{ccc}
1 & \frac{-1}{2} & \frac{-1}{2} \\
0 & \frac{\sqrt{3}}{2} & \frac{-\sqrt{3}}{2}
\end{array}\right]
\end{aligned}
$$

The three-phase positive fundamental current template is constructed as:

$$
\left[\begin{array}{l}
i_{a} \\
i_{b} \\
i_{c}
\end{array}\right]=\sqrt{\frac{2}{3}}\left[\begin{array}{c}
\sin (\omega t) \\
\sin \left(\omega t-\frac{2 \pi}{3}\right) \\
\sin \left(\omega t+\frac{2 \pi}{3}\right)
\end{array}\right]
$$

From (25) is transformed to $(\alpha-\beta)$ reference frame

$$
\left[\begin{array}{l}
i_{\alpha} \\
i_{\beta}
\end{array}\right]=C_{32}\left[\begin{array}{l}
i_{a} \\
i_{b} \\
i_{c}
\end{array}\right]=\left[\begin{array}{c}
\sin (\omega t) \\
-\cos (\omega t)
\end{array}\right]
$$

According to the instantaneous reactive power theory [22], then 
$\left[\begin{array}{l}p \\ q\end{array}\right]=\left[\begin{array}{cc}u_{\alpha} & u_{\beta} \\ u_{\beta} & -u_{\alpha}\end{array}\right]\left[\begin{array}{l}i_{\alpha} \\ i_{\beta}\end{array}\right]$

Where AC and DC components are included

$\left[\begin{array}{l}p \\ q\end{array}\right]=\left[\begin{array}{l}p+\tilde{p} \\ \bar{q}+\tilde{q}\end{array}\right]$

Where $\mathrm{p}$ and $\mathrm{q}$ are passed through low pass-filter (LPF) and DC component is gotten by

$\left[\begin{array}{l}\bar{p} \\ \bar{q}\end{array}\right]=\sqrt{3}\left[\begin{array}{l}U_{1} \cos \left(\theta_{1}\right) \\ U_{1} \sin \left(\theta_{1}\right)\end{array}\right]$

According to Ref. [24], transformation is made

$\left[\begin{array}{l}p \\ q\end{array}\right]=\left[\begin{array}{cc}u_{\alpha} & u_{\beta} \\ u_{\beta} & -u_{\alpha}\end{array}\right]\left[\begin{array}{l}i_{\alpha} \\ i_{\beta}\end{array}\right]=\left[\begin{array}{cc}i_{\alpha} & i_{\beta} \\ -i_{\beta} & i_{\alpha}\end{array}\right]\left[\begin{array}{l}u_{\alpha} \\ u_{\beta}\end{array}\right]$

The DC components of $p$ and $q$

$\left[\begin{array}{l}\bar{p} \\ \bar{q}\end{array}\right]=\left[\begin{array}{cc}u_{\alpha f} & u_{\beta f} \\ u_{\beta f} & -u_{\alpha f}\end{array}\right]\left[\begin{array}{l}i_{\alpha} \\ i_{\beta}\end{array}\right]=\left[\begin{array}{cc}i_{\alpha} & i_{\beta} \\ -i_{\beta} & i_{\alpha}\end{array}\right]\left[\begin{array}{l}u_{\alpha f} \\ u_{\beta f}\end{array}\right]$

The fundamental voltages in $(\alpha-\beta)$ reference frame are:

$\left[\begin{array}{l}u_{\alpha f} \\ u_{\beta f}\end{array}\right]=\left[\begin{array}{cc}i_{\alpha} & i_{\beta} \\ -i_{\beta} & i_{\alpha}\end{array}\right]^{-1}\left[\begin{array}{l}\bar{p} \\ \bar{q}\end{array}\right]=\left[\begin{array}{cc}i_{\alpha} & -i_{\beta} \\ i_{\beta} & i_{\alpha}\end{array}\right]\left[\begin{array}{l}\bar{p} \\ \bar{q}\end{array}\right]$

The three-phase fundamental voltages are specified by

$$
\left[\begin{array}{c}
u_{a f} \\
u_{b f} \\
u_{c} f
\end{array}\right]=C_{23}\left[\begin{array}{l}
u_{\alpha f} \\
u_{\beta f}
\end{array}\right]=\sqrt{2} U_{1}\left[\begin{array}{c}
\sin \left(\omega t+\theta_{1}\right) \\
\sin \left(\omega t+\theta_{1}-\frac{2 \pi}{3}\right) \\
\sin \left(\omega t+\theta_{1}+\frac{2 \pi}{3}\right)
\end{array}\right]
$$

Where

$$
C_{23}=\left[\begin{array}{cc}
1 & 0 \\
-1 / 2 & \sqrt{3} / 2 \\
-1 / 2 & \sqrt{3} / 2
\end{array}\right]
$$

\subsection{Link Voltage Control}

It is assumed that the DC bus is not connected to any battery storage system. Therefore, the total energy needed for compensating a sag voltage may discharge the DC capacitor. This energy should be consumed from the AC grid through the parallel APF by controlling the signal Ic,los or IDC appropriately. However, the DC bus voltage controller governs the power PDC_ref that is the image of the current Ic, los Figure 7.

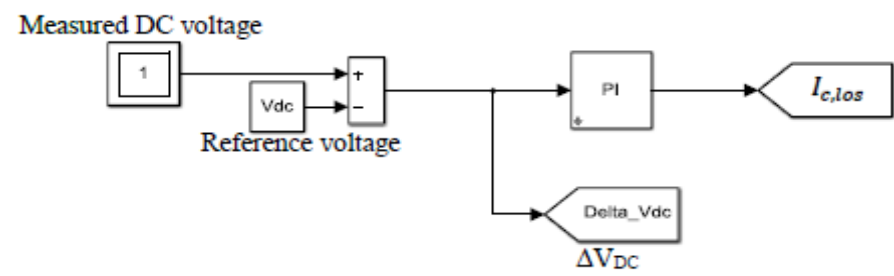

Figure 7. Direct current bus control 
The DC bus voltage passes through a PI controller and then it is added to the oscillating power or current that calculated in the shunt APF control algorithm as shown in Figure 5. Let the voltage error $\triangle$ VDC between the reference DC bus voltage and measured DC capacitors voltage be defined, as follows [23]:

$$
\Delta V_{D C}=V_{D C r e f}-V_{D C}
$$

Adjusting the gains of PI compensators, a fast tracking and zero steady state errors can be achieved. The voltage error has been regulated by a PI controller, then, we have:

$$
I_{D C_{-} r e f}=K_{P} \Delta V_{D C}+K_{I} \int \Delta V_{D C} d t
$$

\subsection{SEPIC converter modelling}

A FCS is integrated with SEPIC, which chops the DC input to the desired output voltage. The power circuit of the SEPIC is shown in Figure 7. Single-ended primary inductance converter, as shown in Figure 8.

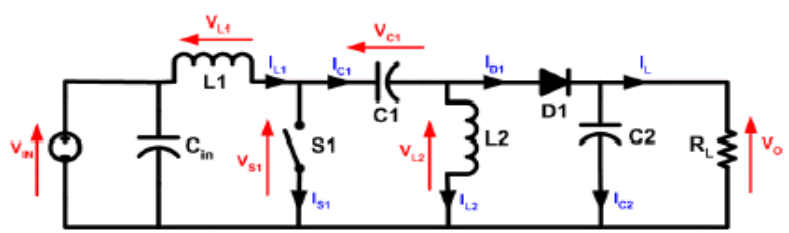

Figure 8. Single-ended primary inductance converter

The converter output voltage is controlled by controlling the duty ratio of the switch $S 1$ that can be stepped up/down. In this proposed topology, the SEPIC is designed for an output voltage varying from (VDC $-\Delta \mathrm{VDC}: \mathrm{VDC}+\Delta \mathrm{VDC})$

\subsection{Proposed method or model}

As the present system is designed for utilizing the FC generator for controlling the DC voltage of the UPQC, SEPIC converter is used to maintain the DC voltage at the required level. A PI controller is used for controlling the SEPIC output voltage. Whereby there is any change in the DC link voltage, the SEPIC converter will inject the difference between the reference and the measured voltage( $\triangle \mathrm{VDC})$ and if there is no change in measured VDC voltage, the PI controller adjusts the duty cycle accordingly and maintains VDC constant across the capacitor. In this case, the output SEPIC voltage has the same voltage as the DC link voltage that means there is no exchange between the SEPIC converter and the UPQC DC link capacitor. Therefore, the FC generator will be in standby mode. The MATLAB Simulink implementation of SEPIC converter with closed loop control is shown in Figure 9.

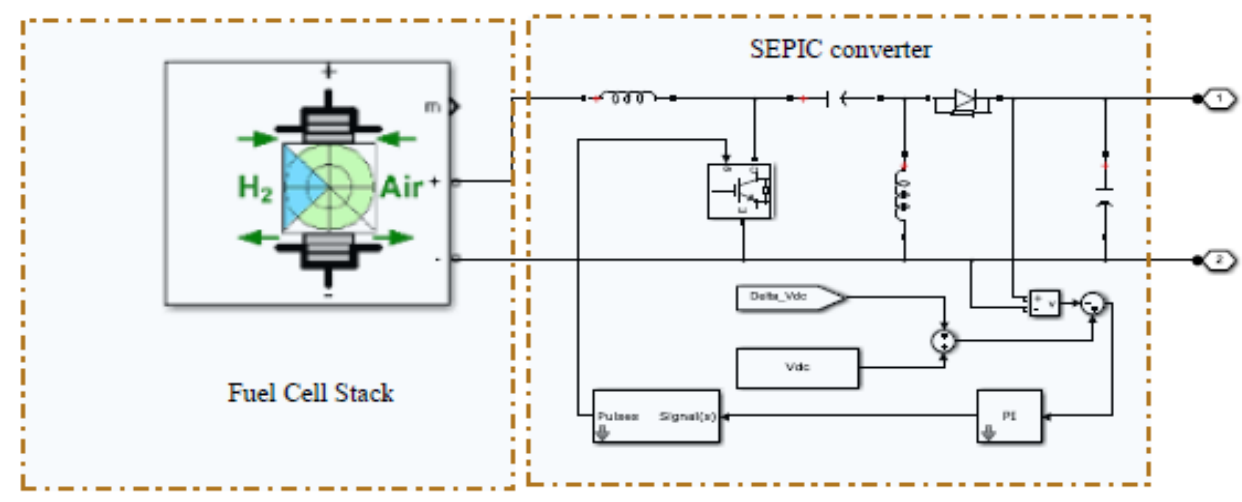

Figure 9. Fuel cell system unites 


\section{RESULTS AND ANALYSIS}

To illustrate the capability of the UPQC-FC for voltage sag mitigation, a three-phase system is considered. The proposed UPQC-PC model is simulated by MATLAB Simulink is shown in Figure 10, to compensate several sag voltage deeps $59 \%, 79 \%$ and $99 \%$ according to the reference voltage $(220 \mathrm{~V})$. The total simulation period is 2 s. In MATLAB Simulink the series part of the UPQC is simulated to be in operation only when the supply voltage differs from its nominal value (220V). When the Fuel Celle System (FCS) generates excessive power, the shunt part of the UPQC will operate to inject this power into grid. The simulation parameters of the proposed system are shown Table 1 on Appendix.

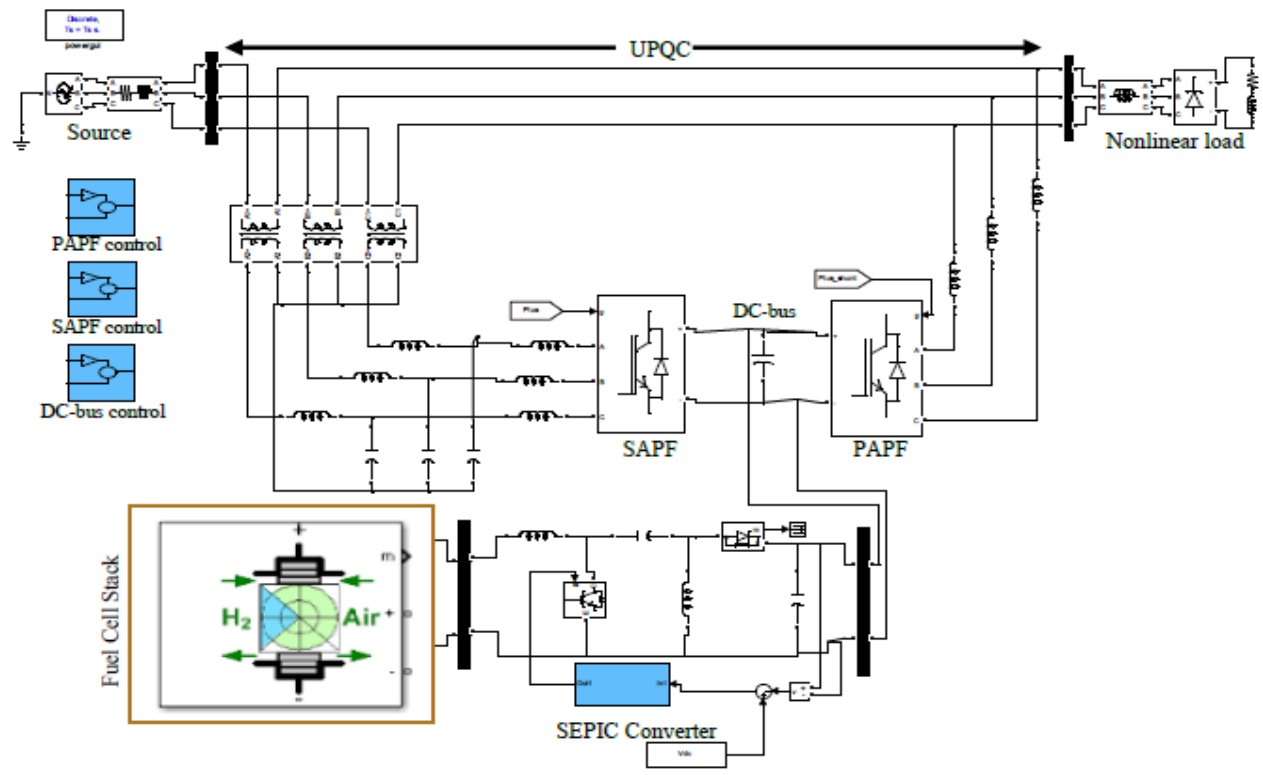

Figure 10. System synoptic scheme

As presented in Figure 11 three different sag voltage deeps are applied during the period $1 \mathrm{~s}-1.6 \mathrm{~s}$ at the source side. These sags are applied in the case when the UPQC is standalone is shown in Figure 11(a) and Figure 11(b) presents the case when the UPQC is supplied by FCS.
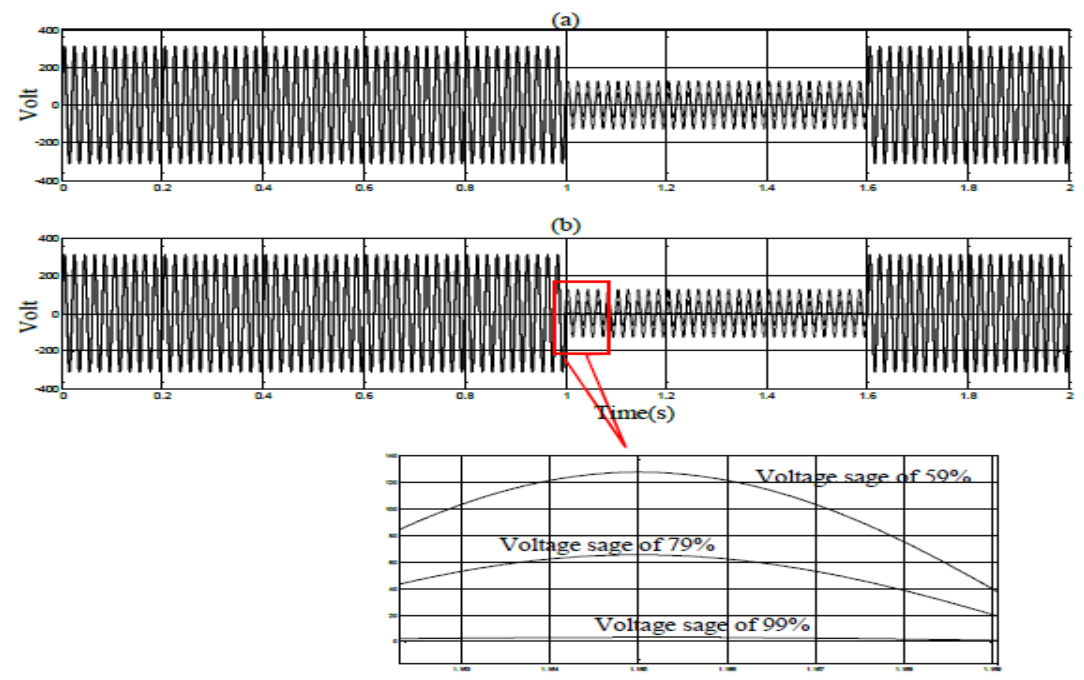

Figure 11. Source voltage (a) UPQC standalone, (b) UPQC supplied by FC system 
The load voltages are shown in Figure 12. From the simulation results, it is observed that the load voltages are unaffected by the voltage variation in the case when the UPQC is feeded by FCS is shown in Figure 12(b). Almost the same results are for the case when the UPQC works without FCS unless the case of $99 \%$ of the voltage sag is shown in Figure12(a).

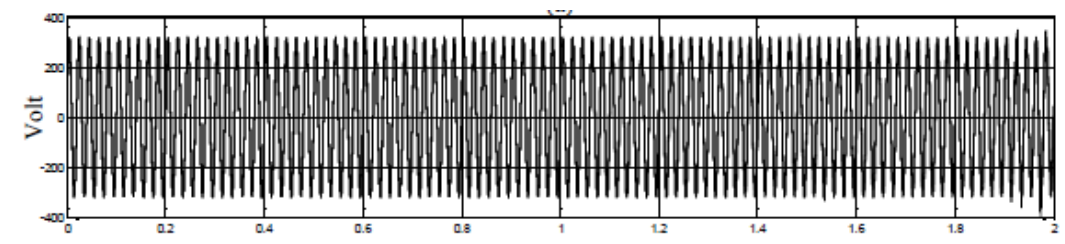

(a)

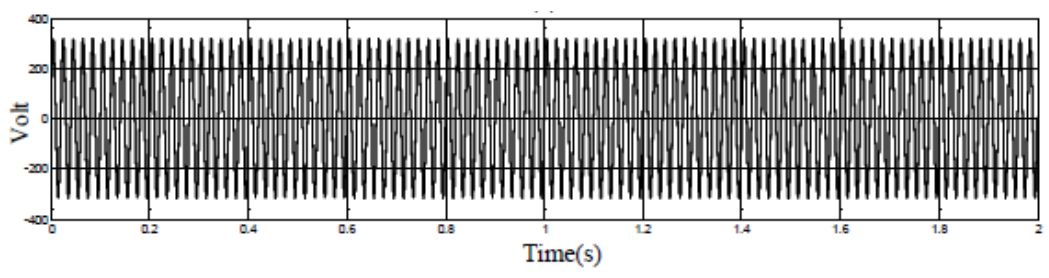

(b)

Figure 12. Load voltage (a) UPQC standalone, (b) UPQC supplied by FC system

The Figure 13 presents the UPQC injected voltages for three sag degrees (59\%, 79\% and 99\%) for the UPQC operation when the FCS is connected or not. As can be seen from these results, the UPQC-FCS is able to produce the required voltage components for different cases rapidly is shown in Figure 13(a). The Figure 13(b) shows the same results unless for the case of $99 \%$ the UPQC is hardly injected the necessary voltage to compensate that voltage sag.

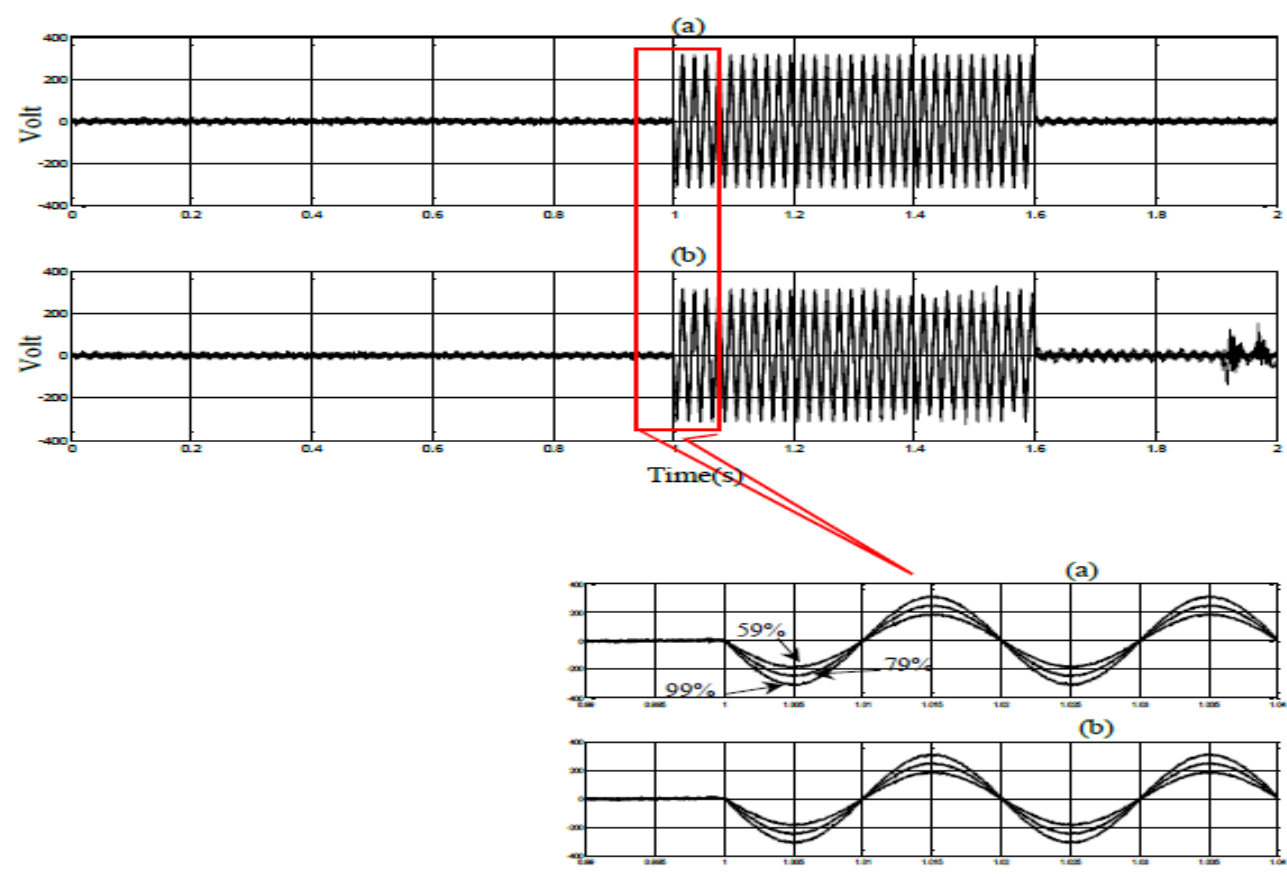

Figure 13. Injected voltage (a) UPQC supplied by FC system, (b) UPQC standalone 
As can be seen in Figure 14, before the application of the sag voltage at $1 \mathrm{~s}$ that the current deformation has being well compensated through the shunt part of the UPQC which the THD passes from $27,25 \%$ in load side to $2,9 \%$ in source side. In this part of simulation (before $1 \mathrm{~s}$ ), the RMS value of source currents for the both cases with or without FCS connection of these currents doesn't exceeds 17A excepting the first transient regime. We can observe that the source current reaches a maximum value of $20 \mathrm{~A}$ and $35 \mathrm{~A}$ for the case of UPQC with and without FCS connection respectively.

After the instant $t=1 \mathrm{~s}$ which the sag voltage is applied the UPQC acts differently between the case when the FCS is connected and the case that it standalone. For the sag voltage of $59 \%$ the source current reaches 40A for UPQC-FCS and 50A for UPQC.

The most critical case is when the sage deep equals $99 \%$ that represent generally an outage voltage according to IEEE standard 1159-1995. When the UPQC is supplied by FC system that voltage sag has caused an important source current increasing which reaches $140 \mathrm{~A}$ and the system seems stable and operates correctly. Contrariwise, when the compensator is standalone the source current exceeds 450A and the system becomes unstable which that system will uncapable to compensate that sag voltage.

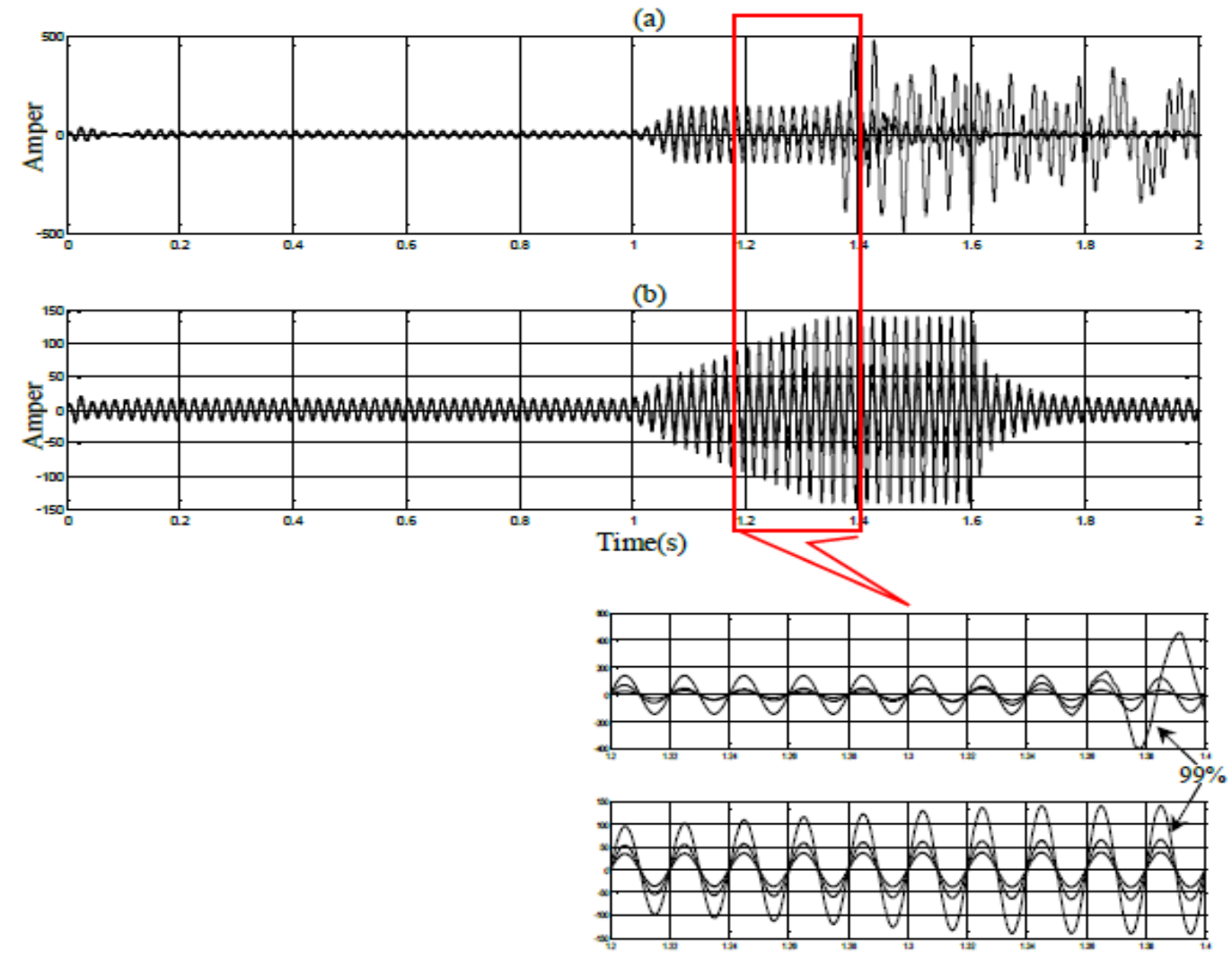

Figure 14. Source current (a)UPQC standalone, (b)UPQC supplied by FC system

The Figure 15 shows the load current for normal operation (before the sag application) that the RMS load current reaches $14,5 \mathrm{~A}$. After $\mathrm{t}=1 \mathrm{~s}$ it seems clearly when the UPQC is supplied by FCS that the RMS load current doesn't change for all the sag deeps. In contrarily and especially for the critical case (99\%) the load current is directly affected by the instability of the UPQC. 


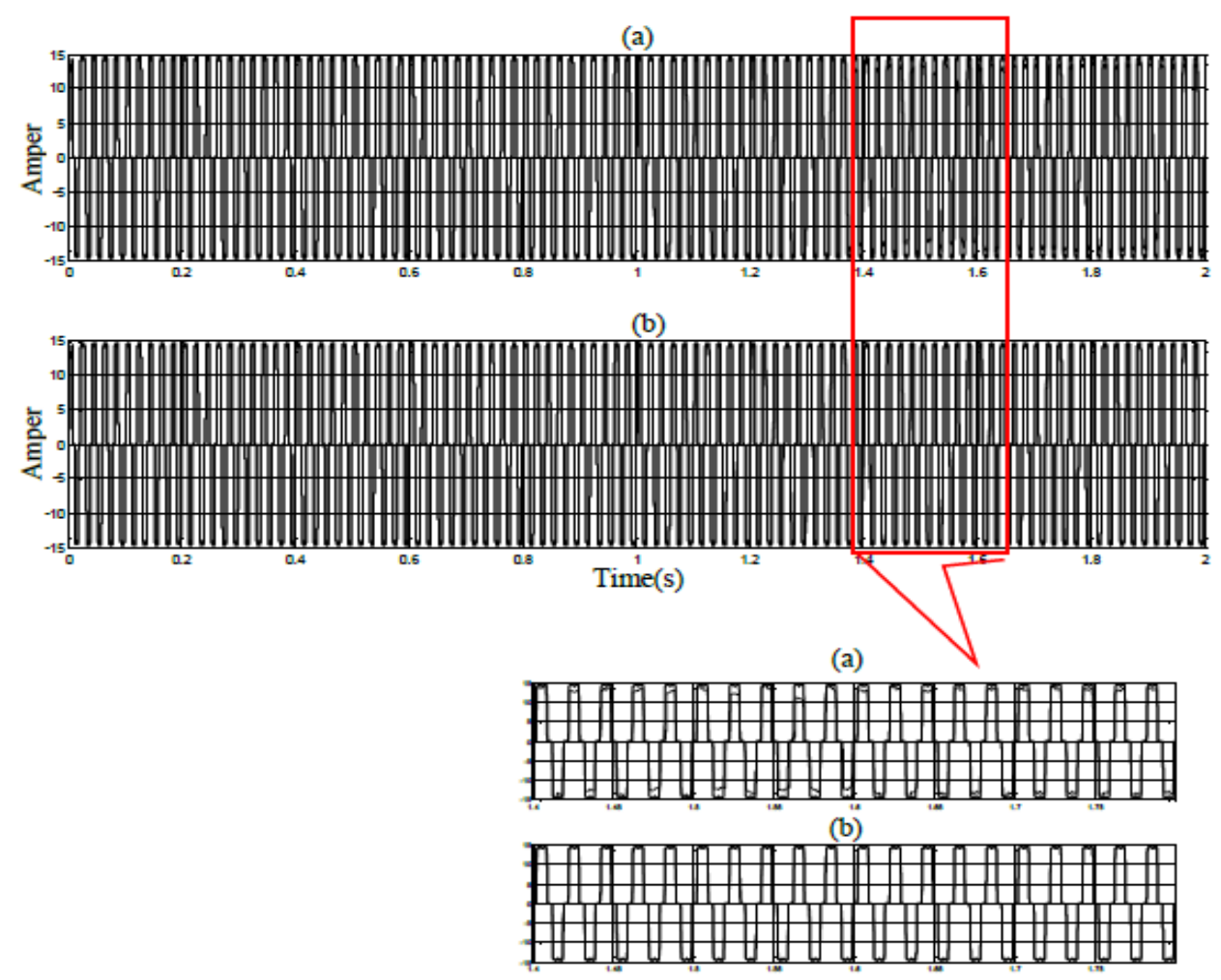

Figure 15. Load current (a)UPQC standalone, (b)UPQC supplied by FC system

From the Figure 16 it is observed that shunt part of the UPQC acts by injecting or absorbing current from the grid to maintain the DC bus voltage constant around its reference voltage $(850 \mathrm{~V})$. The shunt part of the standalone UPQC absorbs currents a maximum of 40A, 120A and 130A for sag voltages of 59\%, 79\% and $99 \%$ respectively. In the Figure 6 .a the shunt active power filter of the combined system (UPQC-FCS) passes current with a maximum of $25 \mathrm{~A}, 50 \mathrm{~A}$ and $125 \mathrm{~A}$ for the previous sag voltages respectively. In addition, for the combined system and after the instant $1,6 \mathrm{~s}$ which the sag voltage $(99 \%)$ is removed, the injected current returns to its previous value. although it remained as it is for the conventional UPQC.

Figure 17 shows the capacitor voltage of the two DC sides of the shunt and series inverters. From this figure cab be identified clearly two different regimes. It shown in first regime that is between instant zero and until almost the instant $\mathrm{t}=0,35 \mathrm{~s}$ which the $\mathrm{DC}$ voltage maximum value exceeds $858,5 \mathrm{~V}$ and doesn't go above $856 \mathrm{~V}$ for the UPQC without and with FCS connection respectively. Furthermore; the transient time takes $0,35 \mathrm{~s}$ and $0,12 \mathrm{~s}$ for the UPQC without and with FCS connection respectively.

The second regime it is about it is about the sag voltage application (between $1 \mathrm{~s}$ and 1,6s). For the critical case $(99 \%)$ and after the sag removing, the DC voltage is quickly established around the reference value $(850 \mathrm{~V})$ which the maximum value does not exceeds $885 \mathrm{~V}$. Contrarily, in the case of conventional UPQC operation the DC bus voltage falling down directly after the sag voltage application (99\%) which the UPQC becomes incapable to control this voltage.

Figure 18 shows the active power supplied from DC bus link to compensate the sag voltage though the series active power filter. As it is shown that before and after the sag voltage period the active power equals zero. During the compensation period between $1 \mathrm{~s}$ and $1,6 \mathrm{~s}$ and for the sag of $59 \%$, the consumed DC power does not exceed $10 \mathrm{~kW}$ and $15 \mathrm{~kW}$ for combined and conventional system respectively.

With regard to the sag of $79 \%$, the DC power does not exceed $28 \mathrm{~kW}$ for the UPQC-FCS and $50 \mathrm{~kW}$ for UPQC. Concerning the critical case $(99 \%)$, the conventional system cannot be able to compensate that sag which the DC power goes above $170 \mathrm{~kW}$ and the system becomes instable. 

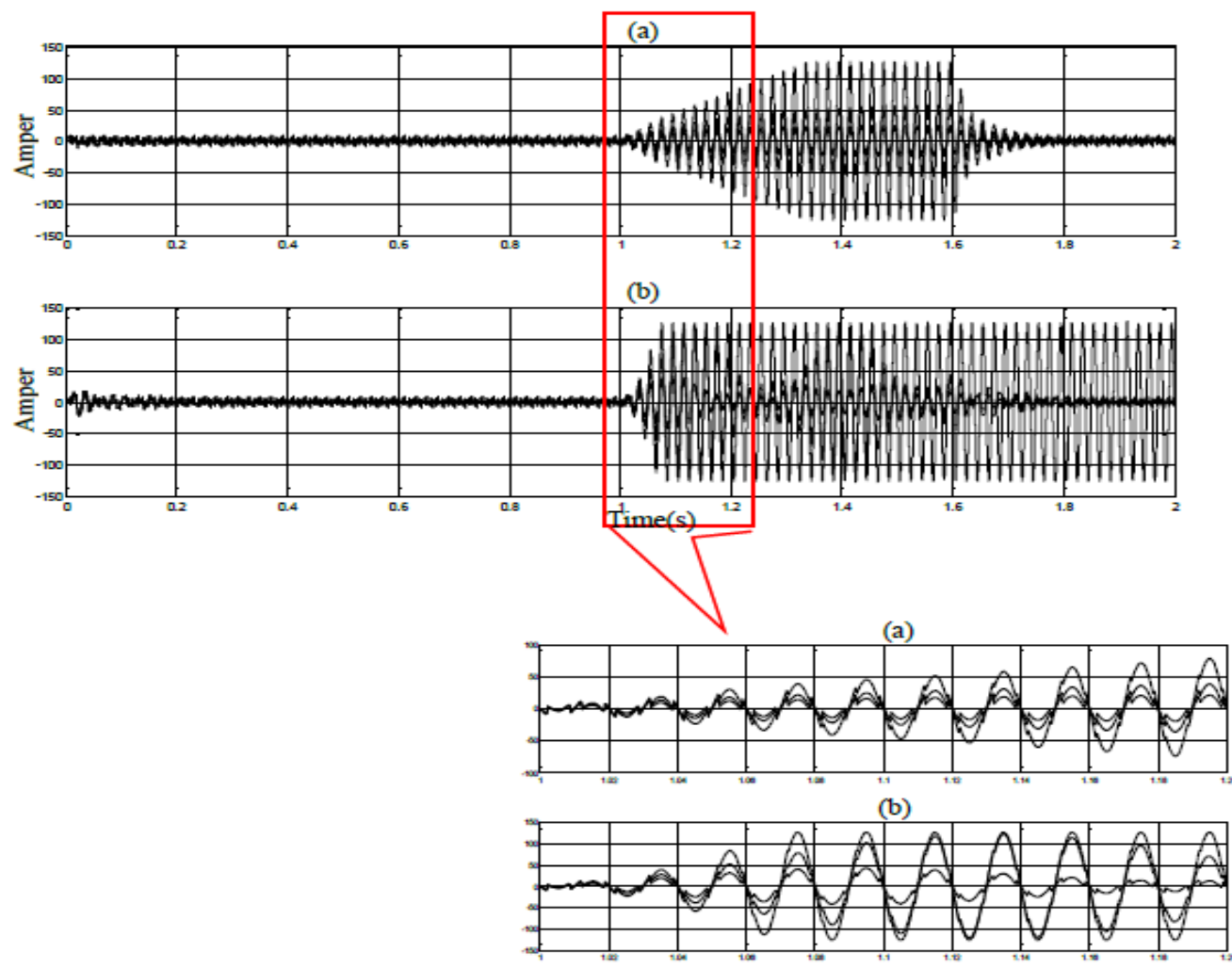

Figure 16. Injected current ((a)UPQC supplied by FC system, (b)UPQC standalone)

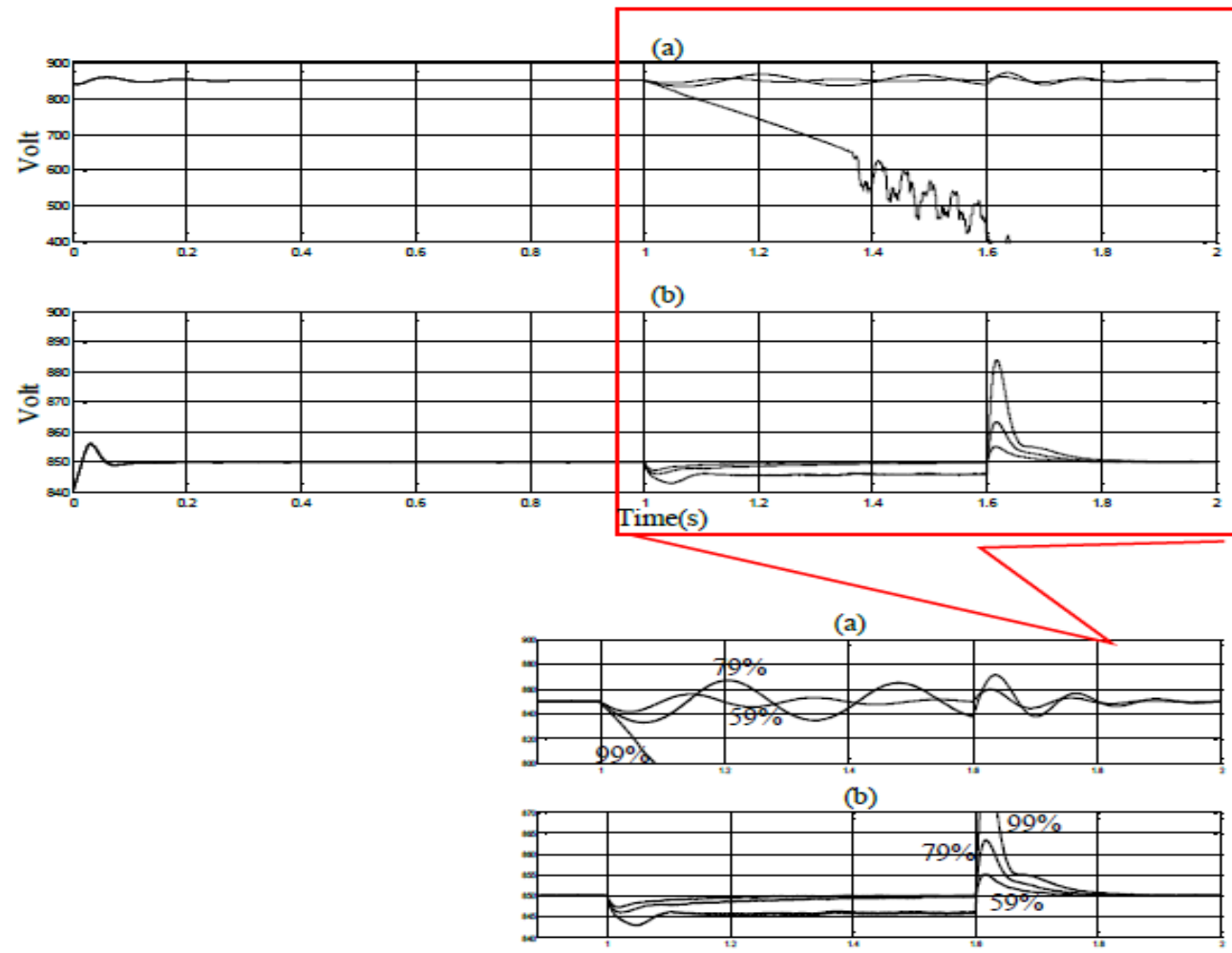

Figure 17. DC link voltage (a)UPQC standalone, (b)UPQC supplied by FC system 


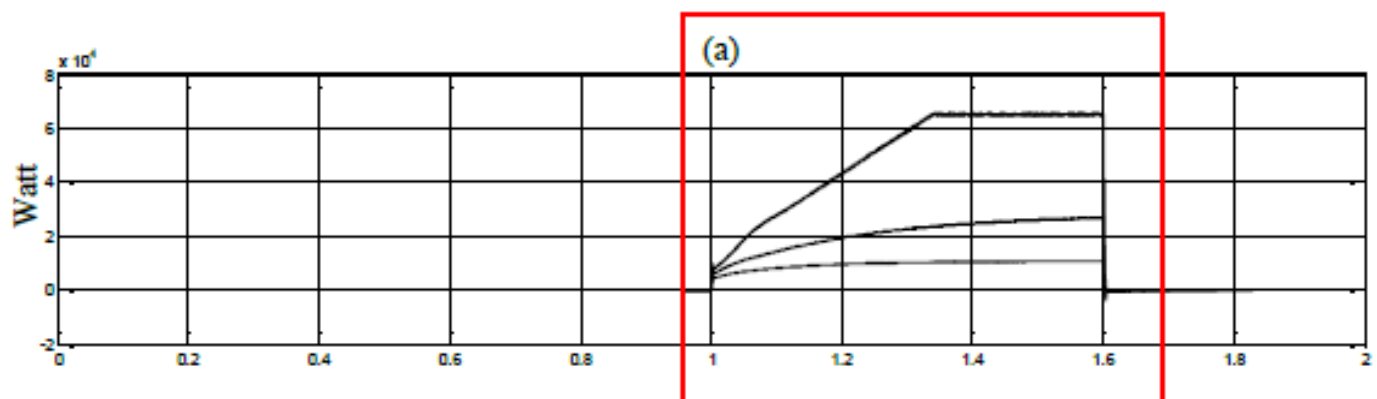

(b)

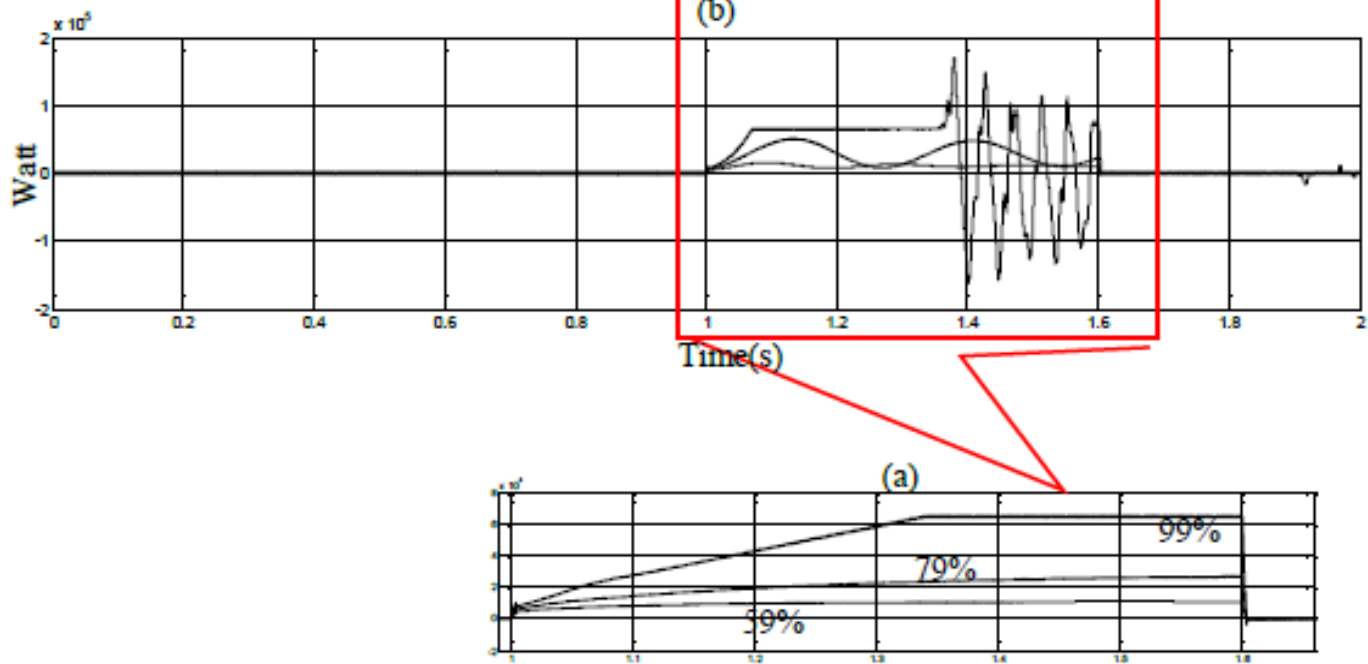

(b)

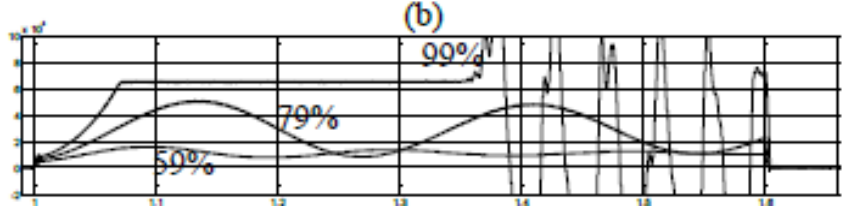

Figure 18. PDC series injected power (a)UPQC supplied by FC system, (b)UPQC standalone

Figure 19 presents the DC active power supplied by the shunt part of the UPQC to maintain the capacitor voltage constant around its reference value. According to these curves there are two important time areas; the first period is about the transient regime for recharging the capacitor. While the second interval is about the voltage sag compensation, which the shunt active filter absorbs from the grid a specific power quantity to maintain a constant DC bus voltage. Through FCS connection, that active power does not exceed $11 \mathrm{~kW}$ and without that connection, it surpasses $19 \mathrm{~kW}$ (sag of 59\%). As we have seen previously the system instability is caused only when the UPQC is standalone (sag of $99 \%$ ).

Figure 20 shows the important of role of the SEPIC converter, which it works to establish the DC bus voltage around its reference, value $(850 \mathrm{~V})$. As it is observed clearly from this figure and during the sag voltage application the DC converter curry more power from FCS, which the FC current is increased from 80 A to almost 100 A during the sag of $99 \%$. During the same sag voltage, the SEPIC output voltage increases from $850 \mathrm{~V}$ to $855 \mathrm{~V}$ to compensate the voltage luck across the capacitor. 

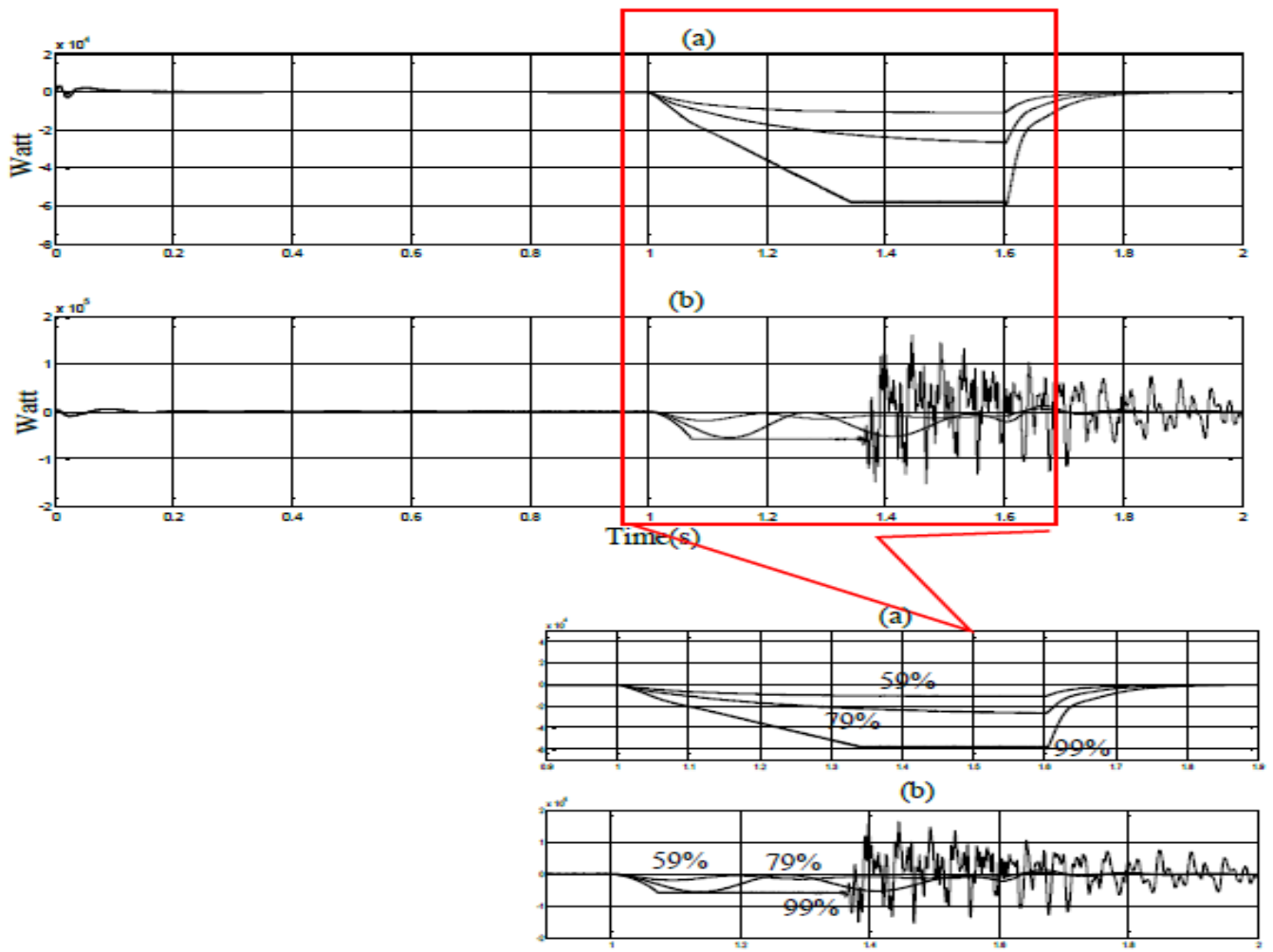

Figure 19. PDC shunt injected power (a)UPQC supplied by FC system, (b)UPQC standalone
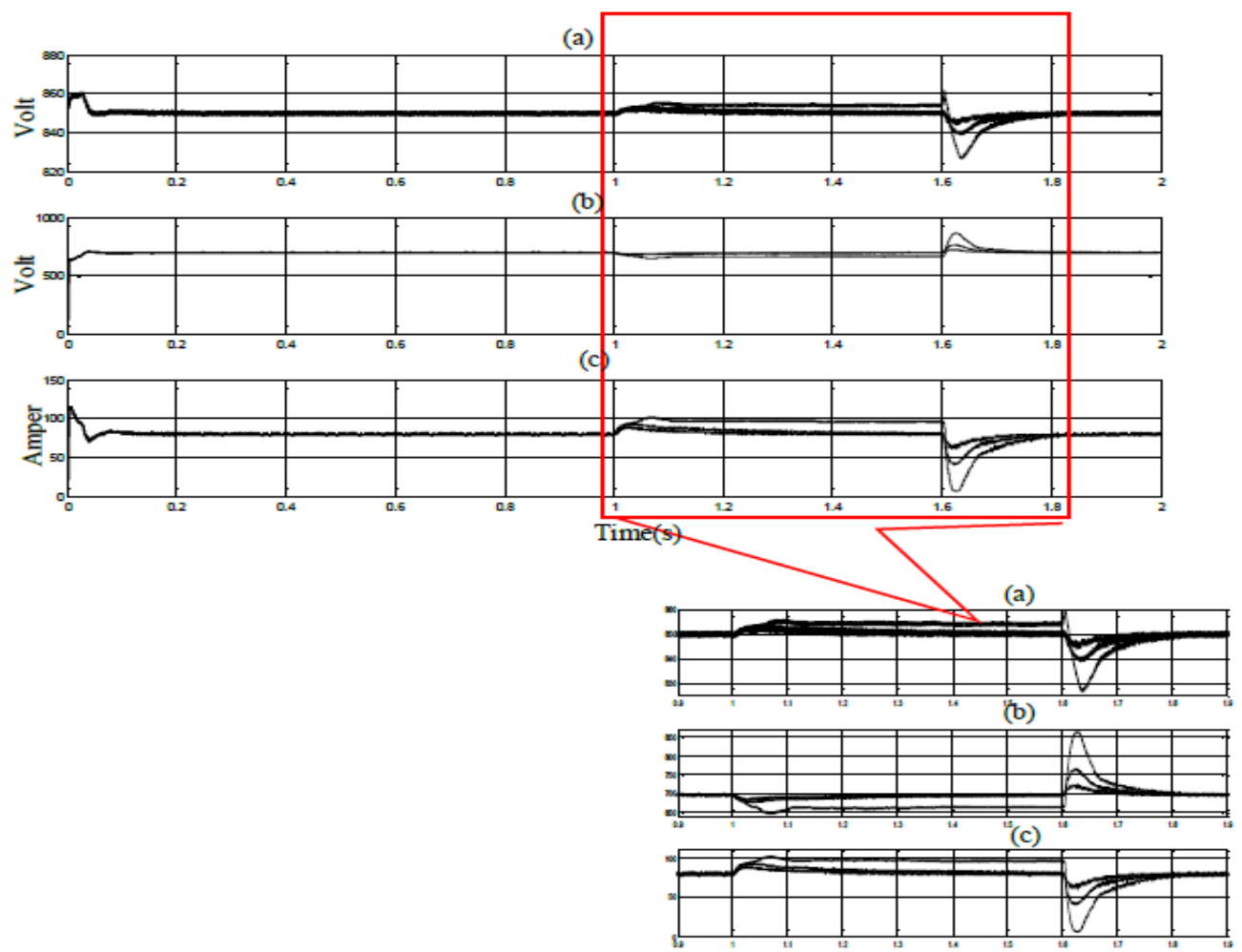

Figure 20. DC system (a)SEPIC output voltage, (b)FC output voltage, (c)FC output current 


\section{CONCLUSION}

In this paper, the performance of an UPQC and FCS system combination was conducted using MATLAB/Simulink simulations. For guaranteeing a good voltage stability arcos the DC bus voltage link, the DC party of the FC system has been controlled by a boos-back converter (SEPIC). The simulation results show that this proposed topology presented a good efficiency for avoiding the DC link voltage disturbance during the sag voltage compensation. Finally, this paper concludes that, when dealing with the combination of the active power filters and renewable energy sources, the investment cost is typically higher, however the sizing of these active filters will be reduced and the design cost will be automatically cheaper regardless of the achieved power quality enhancement.

\section{ACKNOWLEDGEMENTS}

This work was financially supported by the Smart Grids \&Renewable Energies Laboratory, TAHRI Mohammed University of Bechar Algeria, under the scientific Programme application of electronic and power electronic in system of energetic conversion, 2017.

\section{REFERENCES}

[1] Z. Yinhai, et al., "A Novel SVPWM Modulation Scheme," in Applied Power Electronics Conference and Exposition, 2009. APEC 2009. Twenty-Fourth Annual IEEE, pp. 128-131, 2009.

[2] O. Abdelkhalek, A. Kechich, C. Benachiba, "Comparative Study between Two Topologies of an UPQC Six-Leg and an UPQC Seven-Leg," Electrotehnica, Electronica, Automatica, vol. 62, pp.70-78, 2014.

[3] S.Hou, J. Fei, "Adaptive fuzzy back-stepping control of three-phase active power filter" Control Engineering Practice, vol 45, pp. 12-21, 2015.

[4] P Ajitha, D Jananisri, "Voltage Sag Mitigation and Load Reactive Power Compensation by UPQC"in Bulletin of Electrical Engineering and Informatics, vol. 3, pp. 109-112, June 2014.

[5] S. Samal, P K. Hota, "Wind Energy Fed UPQC System for Power Quality Improvement"in Bulletin of Electrical Engineering and Informatics, vol. 7, pp. 495-504, September 2018.

[6] B. Singh, P. Venkateswarlu, "A simplified control algorithm for three phase, four-wire unified power quality conditioner", Journal of Power Electronics, vol. 10, pp. 91-96, 2010.

[7] N. Patnaik, A. K. Panda,"Performance analysis of a 3 phase 4 wire UPQC system based on PAC based SRF controller with real time digital simulation" Electrical Power and Energy Systems, vol. 74, pp. 212-221, 2016.

[8] R. N. Tripathi, A. Singh, T. Hanamoto, "Design and control of LCL filter interfaced grid connected solar photovoltaic (SPV) system using power balance theory", Electrical Power and Energy Systems, vol. 69, pp. 264-272, 2015.

[9] R. Noroozian, M. Abedi, G. B. Gharehpetian and S. H. Hosseini, "On-grid and Off-grid Operation of Multi-Input Single-Output DC/DC Converter based Fuel Cell Generation System", ACEMP'07 and ELECTROMOTION'07 Joint meeting, Bodrum Turkey, Sep. 2007.

[10] J V. Chandrasekar, R.V. Chacko, Z.V. Lakaparampil, "Design and implementation of an energy efficient power conditioner for fuel cell generation system," International journal of hydrogen energy, vol. 36, pp. 15009-15017, 2011.

[11] M. Aguirre, H. Couto, M I. Valla, "Analysis and simulation of a hydrogen based electric system to improve power quality in distributed grids" International Journal of Hydrogen Energy, vol 37, pp. 14959-14965, 2012.

[12] C.K. Sundarabalan, K. Selvi, "Compensation of voltage disturbances using PEMFC supported Dynamic Voltage Restorer" Electrical Power and Energy Systems, vol. 71, pp. 77-92, 2015.

[13] N. Benyahia, H. Denoun, A. Badji, M. Zaouia, T. Rekioua, N. Benamrouche, D. Rekioua, "MPPT controller for an interleaved boost dc-dc converter used in fuel cell electric vehicles," International journal of hydrogen energy, vol 39, pp. 15196-15205, 2014.

[14] R. Seyezhai, BL. Mathur, " Modeling and control of a PEM fuel cell based hybrid multilevel inverter", International Journal of Hydrogen Energy, vol. 36, pp. 15029-15043, 2011.

[15] M. Aguirre, H. Couto, M I. Valla, "Analysis and simulation of a hydrogen based electric system to improve power quality in distributed grids", International journal of hydrogen energy, vol 37, pp. 14959-14965, 2012.

[16] C.K. Sundarabalan, K. Selvi, "PEM fuel cell supported distribution static compensator for power quality enhancement in three-phase four-wire distribution system", International journal of hydrogen energy, vol 39, pp. 19051-19066, 2014.

[17] V. Chandrasekar, V. ChackoRenji, Z V. Lakaparampil, "Design and implementation of an energy efficient power conditioner for fuel cell generation system", International Journal of Hydrogen Energy, vol. 36, pp. 15009-15017, 2011.

[18] G. Mehta,S. P. Singh, R. D. Patidar, "Non-linear load compensation in Fuel Cell grid interfaced system using active power filter", IEEE PEDS 2011, Singapore, 5-8 December 2011.

[19] L. P. Kunjumuhammed, Mahesh K. Mishra "A control algorithm for single-phase active power filter under nonstiff voltage source,” IEEE Trans. Power Electron., vol. 21, pp. 822-825, May 2006.

Unified power quality conditioner supplied by fuel cell system via SEPIC converter (Benabid Slimane) 
[20] A. Chandre, B. Singh, B. N. Singh, K. Al-Haddad, "An improved control algorithm of shunt active filter for voltage regulation, harmonic elimination, power factor correction, and balancing of nonlinear loads", IEEE Transactions on Power Electronics, vol. 15, pp. 495-507, 2000.

[21] S. Chennai, M T. Benchouia, "Unified power quality conditioner based on a three-level NPC inverter using fuzzy control techniques for all voltage disturbances compensation", Front in Energy, vol. 8, pp. 221-239, 2014.

[22] A. Ben Abdelkader, O Abdelkhalek, A. Allali, A. Meftouhi,T. Toumi, "Experimental Validation of Single Phase Series Active Power Filter Using Fuzzy Control Technique," in International Journal of Power Electronics and Drive System (IJPEDS), Vol. 9, No. 2, pp. 591 601, June 2018.

[23] Yahia Bouzelata, Erol Kurt, Rachid Chenni, NecmiAltın, "Design and simulation of a unified power quality conditioner fed by solar energy," international journal of hydrogen energy, 40, 15267 -15277, 2015.

[24] B. Gasmi, O. Abdelkhalak, "Review of the Most Applicable Regulator Collections to Control the Parallel Active Power Filter", in International Journal of Power Electronics and Drive System (IJPEDS), vol. 9, pp. 51-58, March 2018.

\section{APPENDIX}

Table 1. System Parameters

\begin{tabular}{|c|c|}
\hline System Parameters & Value \\
\hline \multicolumn{2}{|l|}{ Power system } \\
\hline Grid voltage & $220 \mathrm{~V}$ \\
\hline Frequency & $50 \mathrm{~Hz}$ \\
\hline Line impedance & $0,01+j 10 e^{-6} \Omega$ \\
\hline Nonlinear load & Three-phase uncontrolled bridgerectifier, $\mathrm{R}_{\mathrm{DC}}=50 \Omega, \mathrm{L}_{\mathrm{DC}}=1 \mathrm{mH}$ \\
\hline \multicolumn{2}{|r|}{ ( } \\
\hline DC link voltage & $850 \mathrm{~V}$ \\
\hline DC link capacitor & $176 e^{-4} F$ \\
\hline PWM switching & $12 \mathrm{KHz}$ \\
\hline Connection filter of shunt filter & $L=59 e^{-4} F$ \\
\hline Connection filter of series filter (RLC) & $L=3,8 e^{-4} F$ \\
\hline \multicolumn{2}{|l|}{ SEPIC } \\
\hline $\mathrm{L} 1=\mathrm{L} 2$ & $109,5 \mu H$ \\
\hline $\mathrm{C} 1$ & $1,380 \mu F$ \\
\hline $\mathrm{C} 2$ & $3300 \mu F$ \\
\hline IL1-MAX & $241,06 \mathrm{~A}$ \\
\hline IL2-MAX & $170 \mathrm{~A}$ \\
\hline \multicolumn{2}{|l|}{ PI controller } \\
\hline $\mathrm{KP}$ & 0,01 \\
\hline KI & 1 \\
\hline PWM frequency & $10 \mathrm{KHz}$ \\
\hline \multicolumn{2}{|l|}{ Fuel cell stack } \\
\hline Nominal power & $50 \mathrm{~kW}$ \\
\hline Nominal current & $80 \mathrm{~A}$ \\
\hline Nominal voltage & $625 \mathrm{~V}$ \\
\hline Maximum power & $120 \mathrm{~kW}$ \\
\hline Maximum Power Point & $280 \mathrm{~A}$ \\
\hline \multicolumn{2}{|l|}{ Current } \\
\hline Maximum Power Point & $430 \mathrm{~V}$ \\
\hline \multicolumn{2}{|l|}{ Voltage } \\
\hline Short circuit current & $315 \mathrm{~A}$ \\
\hline Maximum response time of air supply & $2 s$ \\
\hline Maximum response time of stack with gas oversupply & $1 \mathrm{~s}$ \\
\hline Stack Efficienc & $45 \%$ \\
\hline
\end{tabular}

Int J Pow Elec \& Dri Syst, Vol. 10, No. 1, March 2019: $178-194$ 